\title{
МЕДІАСОЦІОЛОГІЯ
}

Visn. Lviv. Univ., Ser. Zhurn. 2019: 46; 318-324 • DOI: http://dx.doi.org/10.30970/vjo.2019.46.10069

УДК 07:[159.922-049.2:32.019.51]

\section{МАНІПУЛЯТИВНИЙ ВПЛИВ ЗМІ НА СВІДОМІСТЬ В УМОВАХ ІНФОРМАЦІЙНОЇ ВІЙНИ}

\author{
Олена Росінська \\ Київський університет імені Бориса Грінченка, \\ вул. Бульварно-Кудрявська, 18/2, 04053, Київ, Украӥна \\ e-mail: o.rosinska@,kubg.edu.ua \\ https://orcid.org/0000-0003-4460-0668
}

У статті розкрито психологічні основи маніпулятивного впливу ЗМІ на буденну свідомість споживача інформації, проаналізовано методи маніпулятивного впливу. Шляхом опитування респондентів з'ясовано ступінь активності споживання інформації, рівень зацікавленості в різних форматах 3МI, ступінь усвідомлення респондентами специфіки впливу на їхню свідомість.

Ключові слова: буденна свідомість, ЗМІ, маніпулювання, стереотип, технологія.

Постановка проблеми. Кризові періоди в житті суспільства неодмінно відбиваються на стані буденної свідомості, її функціях та механізмах трансформування. Кожна епоха зі своїми ментальними особливостями так чи інакше знаходить відображення в буденній свідомості, що, своєю чергою, формує певні ментальні конструкти. Дослідники різних галузей зосереджують увагу на тих змінах шарів буденної свідомості, що викликані світовою глобалізацією, абсолютною відкритістю інформації, стиранням меж між націями та країнами, доступністю засобів масової інформації. Такі зміни в самому полі формування буденної свідомості потребують грунтовного осмислення в різних площинах, зокрема міждисциплінарного вивчення (психологія - теорія масової комунікації - філософія тощо).

Дослідження основане на низці теорій: психосемантичний підхід до вивчення свідомості людини (О. Ф. Бондаренко, В. Ф.Петренко, О. А. Лапшова), теорія буденної свідомості (С. Б. Кримський, Н. Л. Мусхелішвілі), теорія суспільної свідомості (Л. С. Виготський та А. Н. Леонтьєв, О. М. Лозова); теорія впливу ЗМІ (Дж. Клаппер, Л. А. Найдьонова, В. О. Попова, Ж. Бодрійяр, М. Маклюен), теорії поєднання реального та ілюзорного в буденній свідомості (Ф. Гарифіллін, В. Ф. Казібекова, О. Улибіна), теорія етнічних стереотипів (О. М. Лозова, В. Ф. Петренко, О. В. Улибіна), теорія соціальних стереотипів (В. Ліппман, Л. П. Мардієва, С. Г. Осьмачко), теорія маніпулювання масовою свідомістю (С. Г. Кара-Мурза).

(C) Росінська О., 2019 
На сьогодні буденна свідомість досліджується як універсальна культурно-історична категорія, що функціонує та розвивається за власними внутрішніми законами, натомість сутність буденної свідомості не є вповні проясненою, що стимулює подальше осмислення поняття, у тому числі в контексті впливу медіа на свідомість.

Мета дослідження полягає у з’ясуванні найбільш поширених засобів впливу 3МІ на буденну свідомість українського суспільства.

Медіа як засіб впливу на свідомість адресата найраніше почали вивчати в американській традиції, передусім йшлося про ефективність ЗМІ та міру їхнього впливу, що пояснюється природою соціального замовлення, поставленого перед дослідниками. У роботі Дж. Клаппера «Вплив масової комунікації» (1960р.), котра вважається класичною у висвітленні цих питань, не диференціюються методи чи особливості впливу на свідомість різних видів масової інформації, натомість узагальнюються характеристики такого впливу будь-яким каналом інформування: «масова комунікація, як правило, не є необхідним і достатнім джерелом змін, але скоріше функціонує серед і через посередництво мережі опосередкованих факторів та впливів», хоча «зберігаються певні виняткові ситуації, у яких, вочевидь, масова комунікація здатна чинити прямий вплив» [1]. У цьому й інших дослідженнях підкреслюється, що ЗМІ є потужним засобом формування поглядів, причому це відбувається тим більш ефективно, чим менше сформовані погляди та уявлення споживача інформаціï. Користуючись різними механізмами впливу, засоби масової інформації не просто відображають реальність, а конструюють їі. Якщо говорити про відображення в буденній свідомості певних соціальних реалій, то варто враховувати, що це будуть несистематизовані масові уявлення, що виникають стихійно, базуючись на повсякденному досвіді, пропонованому ЗМІ «порядку денному».

Для розуміння особливих механізмів, які застосовують ЗМІ для формування буденної свідомості, слід розглянути основні підходи до аналізу цього питання. До методів маніпуляції, на думку В. О. Попова, належать такі: «1. Метод зсуву від реалістичної свідомості до аутистичної. Метою реалізації мислення є створення правильних уявлень про дійсність, а метою аутистичної свідомості - створення приємних уявлень і витіснення неприємних. 2. Метод переносу факту приватного у сферу загального, у систему. Цей метод маніпулювання масовою свідомістю заснований на використанні одиничного епізоду в житті суспільства як цілісної сформованої системи. 3. Метод привернення уваги до певних проблем. Основними важелями маніпулювання масовою свідомістю при реалізації цього методу є телебачення, Інтернет та інші 3МI. 4. Метод «переключення» уваги - часто використовується, коли необхідно відвернути населення від гострих соціально-економічних проблем. 5. Метод «залякування» - полягає в необхідності вибору меншого з двох зол. 6. Метод навіювання - передбачає уведення масової свідомості в так званий «сугестивний стан». У цьому випадку слухач (читач, глядач) сприймає все на віру, не потребуючи доказів» [8, с. 88]. Використання названих методів полягає у формуванні в буденній свідомості спотвореної картини світу для подальшого маніпулювання з метою отримання чи втримання влади, економічного впливу тощо. Такий потужний вплив друкованих засобів масової інформації, телебачення, радіо й інтернету пояснюється досить високим рівнем довіри громадян ЗМІ.

Уплив ЗМІ передусім спрямований на формування конструктів масової свідомості. Масова свідомість охоплює найбільш поширені у певному суспільстві знання, 
уявлення, установки, цінності, ідеали, традиції на рівні буденної свідомості, але відображає лише ті з них, які є загальними, типовими для певної сукупності індивідів, певної соціальної спільності» [15]. Стан масової свідомості, що формується переважно засобами масової інформації, безпосередньо відображається на тих уявленнях, що лягають в основу картини світу індивідуума на рівні його буденної свідомості.

Маніпулятивність як одна з ключових властивостей технологій 3МІ на сьогодні реалізується ненасильницьки і грунтується переважно на ненавмисному обмані. Від споживача інформації приховані справжні мотиви маніпуляції та спосіб агресивного впливу - управління увагою й свідомістю. Як правило, маніпулювання свідомістю відбувається під гаслами свободи висловлювання, однак свобода саме втрачається в цьому процесі знищення аутентичності свідомості. Адже інформаційна маніпуляція $\epsilon$ найбільш ефективною формою придушення свободи, причому поза усвідомлення особистістю цього процесу. Усе відбувається непомітно, але неухильно без свободи сприймання. Мислення навіть не формується, бо автономне смислоутворення суб'єкта заміщується нав'язуваними думками, поглядами, смаками, переконаннями тощо.

«Контекст агресивності цього феномена, його непідвладності соціальному контролю пояснюється ще й тим, що це відносно новий феномен, адекватна соціальна реакція на який ще не відбулася. Тут засмічення інформаційного середовища формування людської свідомості можна зіставити із забрудненням природного середовища людини: до недавнього часу прямі наслідки технологічного впливу на природу не сприймалися як явища, що загрожують людині; на поступове усвідомлення цього факту було витрачено десятиліття» [4, с.43]. Саме тому людство має усвідомити інформаційне середовище як середовище свого буття й формування свідомості, а не тільки як комплекс різних відомостей для цієї свідомості.

Аналізуючи механізми психологічного впливу засобів масової інформації на свідомість індивіда, варто враховувати дві основоположні теорії такого впливу. 1. Теорія комунікативного впливу і маніпуляції, суть якої полягає в урахуванні того, що людина миттєво отримує й повністю приймає призначене для неї інформаційне повідомлення, піддаючись впливу, якому важко протистояти. Розглядаючи маніпулятивні функції ЗМІ, дослідники визнавали їхню провідну роль в ідеологізації економічного базису в інтересах провідного класу. У подальшому, зокрема після другої світової війни, відверто маніпулятивне використання ЗМІ критикувалося через економічне, політичне й соціальне відчуження, конформізм масової людини, поширення стандартизованої культури [6]. 2. Теорія задоволення інформаційних потреб аудиторії. «Індивідуальні інформаційні потреби, як і будь-які інші, реалізуються в специфічних, притаманним тільки їм, сенсорній чутливості й швидкості реагування. Відчуття недостатності інформованості, вірогідно, формується в системі «Я / не Я», яка розвивається відповідно до індивідуальної генетичної програми розвитку й соціальних умов розвитку і яка відповідає за постійний контроль і самоаналіз» [9, с. 128]. Таким чином, «інформаційна потреба - це потреба в інформаційній діяльності, що усуває дисбаланс (неузгодженість між наявним і нормальним станом) інформаційної сфери суб'єкта» [9].

Теорія задоволення інформаційних потреб описує мотиви, які змушують людей звертатися до засобів масової інформації. Основна ідея теорії така: головна мотивація - задовольнити певні потреби, зокрема, потребу в спостереженні, потребу в 
персональній ідентифікації, потребу у формуванні особистісних відносин, потребу в приємному проведенні часу.

Уплив ЗМІ на свідомість людини підкорено двом проаналізованим вище фундаментальним законам, що випливають зі специфіки людського сприймання себе й світу, а також реакцій на інформацію. При цьому, спираючись на потребу споживача інформації в її отриманні, ЗМІ можуть вдаватися до досить потужного маніпулювання свідомістю, використовуючи механізми, що грунтуються на здобутках психолінгвістики.

Інформаційне суспільство потребує постійного продукування й поширення інформації, що базується на потужній інформаційній потребі, відповідно. Це питання серйозно досліджувалося, зокрема, В. Ф. Іванов розкриває особливості формування поняття інформаційної потреби [3, с. 47], А. Асланов аналізує роль друкованих 3МІ у задоволенні інформаційної потреби [2], С. П. Кульчицький досліджує інформаційний цикл [5], А. М. Паніна визначає особливості інформаційних потреб [7] тощо.

Для оцінки рівня усвідомлення респондентами впливу медіа на свідомість та здатності аналізувати зміст медіа-контенту нами було проведене опитування серед студентів першого курсу щодо зумовленості інформаційних потреб. Особливість обраних для опитування респондентів полягає в тому, що вони планують пов’язати свою професійну діяльність зі сферою засобів масової інформації (робота в ЗМІ різних форматів). Вік опитуваних цієї групи - 16-18 років, 87,1\% становлять жінки, $12,9 \%$ - чоловіки. Паралельно проводилося опитування батьків абітурієнтів Київського університету імені Бориса Грінченка, що дає можливість порівняти певні позиції. Вік опитуваних цієї групи - 35-52 роки, стать - 96\% жінки, 4\% - чоловіки.

При опитуванні двох груп респондентів для аналізу їхніх інформаційних потреб ми отримали показники, що дозволяють диференціювати спрямованості інформаційної потреби двох вікових категорій (студентів та їхніх батьків). Дослідження демонструє істотну відмінність у показниках потреби респондентів у пізнавальному (батьки $-60 \%$, студенти - 18,9\%) та розважально-інформаційному контенті (батьки $17 \%$, студенти - 73,8\%), що зумовлює користування певними джерелами інформації та структурування засобів впливу в залежності від запиту споживача інформації.

Наступний параметр аналізу - канали отримання інформації, що з психологічного погляду дозволяє оцінити переважний засіб впливу - аудіальний чи візуальний. Опитування демонструє, що для молодшого покоління переважними джерелами інформації є онлайн-канали, а для старшого покоління - телебачення. Відповідно, старше покоління потребує транслювання переважно сформованої точки зору на події, дозованої інформації з регламентацією в часі, що не передбачає зворотного зв’язку, натомість молодше покоління потребує інформаційної відкритості, можливості продемонструвати свою точку зору з приводу отриманої інформації, можливість вільно добирати джерело інформації. Для молоді важливі відсутність дозованості та часової обмеженості.

Переглядаючи відеоконтент у будь-якому форматі (телебачення чи онлайн-канали), споживач інформації підпадає під вплив вербальних та паралінгвістичних засобів, відповідно, може піддаватися різного роду маніпуляціям. Рівень впливу ЗМІ на формування конструктів буденної свідомості визначається також частотністю споживання контенту. 
Більшість опитаних (81,1\%) отримує інформацію з того чи іншого інформаційного каналу щодня, 15,1\% опитаних удається до інформації ЗМІ 2-3 рази на тиждень; споживають інформацію 1 раз на тиждень 1,9\% та дуже рідко - 1,9\%. Таким чином, більшість опитаних регулярно піддається впливу засобів масової інформації. При цьому рівень довіри опитуваних 2 групи (батьки) до засобів масової інформації досить високий - 43,6\%, і 3МІ займають 1 місце серед джерел інформації, яким довіряють представники цієї групи. Практично такий же відсоток опитуваних цієї групи 41,9\% визнають, що ЗМІ формують їхні уявлення про світ, впливають на світобачення, свідомість. 41,6 відсотків довіряють 3МІ й 41,9 визнають, що ЗМІ впливають на їхню свідомість.

Опитувані 1-ї групи (студенти) продемонстрували близькі статистичні показники рівня довіри телебаченню та рівня визнання його впливу (37 та 30\%), радіо (5,6 та 4\%). Істотно різняться при цьому показники рівнів довіри та впливу блогів та соцмереж (11,1 та 34\%), отже, респонденти визнають потужний вплив соціальних мереж на свідомість навіть при досить низькому показникові довіри.

Показово, що респонденти обох груп опитуваних указують на те, що довіряють засобам масової інформації тільки частково - 96,2\%. Повністю довіряють ЗМІ 3,8\%. Жоден з респондентів не відповів, що повністю не довіряє засобам масової інформації.

Для оцінки вірогідності впливу засобів масової інформації на буденну свідомість важливим показником є чинники, які, на думку респондентів, сприяють довірі до повідомлюваної інформації, оскільки саме імітація цих показників вірогідності стає основою для маніпулювань з інформацією. Так, 52,9\% респондентів називають таким чинником власну оцінку правдивості отриманої інформації, тобто критичне сприймання повідомлюваного. На другому місці серед чинників вірогідності інформації - репутація ЗМІ $(26,4 \%)$ та його авторитетність $(15,1 \%)$.

За шкалою від 1 до 10 респонденти таким чином оцінюють свою здатність аналізувати адекватне відображення навколишньої дійсності засобами масової інформації: $5-18,9 \%, 6-24,5 \%, 7-34 \%, 8-18,9 \%, 9-1,9 \%, 10-1,9 \%$. Тобто з усіх опитуваних тільки один вважає, що має абсолютну здатність оцінювати якість контенту.

Таким чином, сучасне інформаційне суспільство з усією різноманітністю каналів та форматів поширення інформації справляє потужний вплив на особистість та iii свідомість. Респонденти двох різних вікових категорій (студенти і батьки) демонструють усвідомлення такого впливу на досить високому рівні, а також усвідомлення своєї нездатності аналізувати адекватність отриманої інформації на 100\%.

\section{REFERENCES}

1. Joseph T. Klapper. The effects of mass communication / Joseph T. Klapper. Free Press, 1960. $328 \mathrm{c}$.

2. Асланов А. Роль преси і інформаційних агентств у забезпеченні інформаційних потреб населення [Електронний ресурс] / А. Асланов. Режим доступу: http:// archive.nbuv.gov.ua/portal/Soc_Gum/Gileya/2010_33/ Gileya33/I15_doc.pdf. Заголовок з екрану

3. Іванов В. Ф. Інформаційні потреби суспільства [Текст] / В. Ф. Іванов // Інформаційне суспільство: наук. журн. / гол. ред. В. Ф. Іванов. К., 2010. №12. С. 47. 
4. Кузнецова Т. В. Контрадикции информационно-коммуникативных сфер формирования культуры общества: искусство, масс-медиа, образование / Т. В. Кузнецова, Е. Е. Ланкина, Е. А.Торопчина // Вестник ТГПУ. 2006. Вып. 12 (63). Серия: Гуманитарные науки. С. 74-80.

5. Кулицький С. П. Основи організації інформаційної діяльності у сфері управління [Текст]: навч. посіб. / С. П. Кулицький. К.: МАУП, 2002. 222 с.

6. Ніт Д.І. Проблема спотворення соціальної реальності [Електронний ресурс]. / Д. I Ніт // Електр. дан. (1 файл) - Режим доступу: http://lib.socio.msu/l/library. Загол. з екрану.

7. Паніна А. М. Інформаційна потреба як складова інформаційної культури особистості [Електронний ресурс] / А. М. Паніна. Режим доступу: http://mdgukid.at.ua/ publ/informacijna_potreba_jak_kladova_informacijnoji_kulturi_osobistosti/1-1-0-65. Загол. з екрану

8. Попова В. О. Роль средств массовой информации в формировании стереотипов массового сознания / В. О. Попова, Е. А. Балезина // Философия. Психология. Социология. 2015. Вып. 2. С. 88-94.

9. Седякин В. П. О теории информационных потребностей / В. П. Седякин, И. В. Соловьев, С. В. Разливинская // Прикладная информатика. 2013. № 3. С. 127-133. 


\title{
MANIPULATIVE INFLUENCE OF MEDIA IN INFORMATION WARFARE CONDITIONS
}

\author{
Olena Rosinska \\ Borys Grinchenko Kyiv University, \\ 18/2 Bulvarno-Kudriavska Str, 04053, Kyiv, Ukraine \\ e-mail: o.rosinska@kubg.edu.ua \\ https://orcid.org/0000-0003-4460-0668
}

The article reveals the psychological foundations of the manipulative influence of the media on the everyday consciousness of the consumer of information, analyzes the methods of manipulative influence. The survey of respondents has determined the degree of activity of information consumption, the level of interest in various media formats, the degree of awareness of respondents of the specificity of their influence on their consciousness.

The methods of media influence on ordinary consciousness include various types of fragmentation of information, game by facts and figures, logic violations, semantics (use of metaphors, emotionally evaluated vocabulary, language of symbols, archetypes, antitheses) of stereotypical images for attaching certain connotative stereotypes to the consciousness in order to strengthen influence and others. Consequently, the technologies of influence determine the need for psychosemantic analysis to study stereotypical, mythological and archetypal images of everyday consciousness. The research demonstrates the relevance of the psychosemantic approach to the study of everyday consciousness in the modern information society, the impact of crisis processes in the development of society on the changes in certain levels of everyday consciousness and the main directions of its transformation, as well as the empirical research of the formation of the ominous everyday consciousness by mass media has been demonstrated.

The author proposes a hypothesis according to which manipulative means used by mass media with support on stereotyped and archetypal foundations of everyday consciousness are the basis for the formation of a mistake, while:

- the ability to manipulate is not influenced by the education of the respondent,

- age has little effect;

- the region of residence is a partial factor in the stereotyped perception of certain manipulative ideas.

Key words: everyday consciousness, mass media, manipulation, stereotype, technology. 